\title{
Optimization and validation of RT-LAMP assay for diagnosis of SARS-CoV2 including the globally dominant Delta variant
}

Vijay Lakshmi Jamwal ${ }^{1,2}$, Natish Kumar ${ }^{1}$, Rahul Bhat ${ }^{1,2}$, Piyush Singh Jamwal ${ }^{1}$, Kaurab Singh ${ }^{3}$, Sandeep Dogra ${ }^{4}$, Abhishek Kulkarni ${ }^{5}$, Bhaskar Bhadra ${ }^{5}$, Manish R. Shukla ${ }^{5}$, Saurabh Saran ${ }^{1,2}$, Santanu Dasgupta ${ }^{5}$,

Ram A. Vishwakarma ${ }^{1}$ and Sumit G. Gandhi ${ }^{1,2^{*}}$

\begin{abstract}
Background: Severe Acute Respiratory Syndrome Coronavirus 2 (SARS-CoV-2), the causative agent of COVID-19 pandemic, has infected more than 179 million people worldwide. Testing of infected individuals is crucial for identification

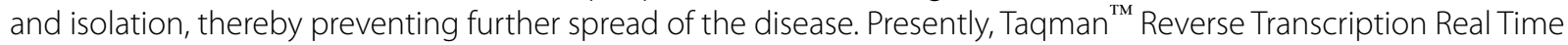
PCR is considered gold standard, and is the most common technique used for molecular testing of COVID-19, though it requires sophisticated equipments, expertise and is also relatively expensive.
\end{abstract}

Objective: Development and optimization of an alternate molecular testing method for the diagnosis of COVID-19, through a two step Reverse Transcription Loop-mediated isothermal AMPlification (RT-LAMP).

Results: Primers for LAMP were carefully designed for discrimination from other closely related human pathogenic coronaviruses. Care was also taken that primer binding sites are present in conserved regions of SARS-CoV2. Our analysis shows that the primer binding sites are well conserved in all the variants of concern (VOC) and variants of interest (VOI), notified by World Health Organization (WHO). These lineages include B.1.1.7, B.1.351, P.1, B.1.617.2, B.1.427/B.1.429, P.2, B.1.525, P.3, B.1.526 and B.1.617.1. Various DNA polymerases with strand displacement activity were evaluated and conditions were optimized for LAMP amplification and visualization. Different LAMP primer sets were also evaluated using synthetic templates as well as patient samples.

Conclusion: In a double blind study, the RT-LAMP assay was validated on more than 150 patient samples at two different sites. The RT-LAMP assay appeared to be $89.2 \%$ accurate when compared to the Taqman ${ }^{\text {TM }}$ rt-RT-PCR assay.

Keywords: B.1.1.7 (Alpha), B.1.351 (Beta), P.1 (Gamma), B.1.617.2 (Delta), B.1.427, B.1.429 (Epsilon), P.2 (Zeta), B.1.525 (Eta), P.3 (Theta), B.1.526 (lota), B.1.617.1 (Kappa), COVID-19, Loop-mediated isothermal amplification, Molecular diagnosis, RT-LAMP, SARS-CoV-2

*Correspondence: sumit@iiim.res.in; sumitgandhi@gmail.com ${ }^{1}$ CSIR-Indian Institute of Integrative Medicine, Canal Road, Jammu 180001, India

Full list of author information is available at the end of the article

\section{Introduction}

Severe Acute Respiratory Syndrome (SARS) is a respiratory disease caused by a coronavirus that appears to have jumped from horseshoe bats to humans $[1,2]$. SARS outbreak, caused by the SARS-CoV, occurred during 2002-2004 [3]. A similar respiratory disease caused by another coronavirus, which originated in the Middle East, resulted in an outbreak during the 2012-2013 and 
was named Middle East Respiratory Syndrome (MERS). MERS is caused by a MERS-CoV, which is believed to have jumped from bats to camels and then infect humans $[4,5]$. Recently, towards the end of 2019 another coronavirus, named SARS-CoV-2 resulted in an outbreak of Coronavirus Disease 2019 (COVID-19). Since the outbreak, COVID-19 pandemic has infected more than 179 million people worldwide resulting in death of about 3.9 million people. Few countries such as Israel and others from the Western Pacific Region have been able control the outbreak significantly (https://covid19.who.int/). Vaccination, social distancing, general hygiene, contact tracing and most importantly, diagnostic testing for COVID-19 in high numbers, are considered to be important factors in controlling spread of the disease $[6,7]$. Transmissibility of SARS-CoV-2 was found to be about $55 \%$ with approximately $30 \%$ of individuals remaining asymptomatic [8]. However, new variants, such as the Delta appears to exhibit prominently higher transmissibility attributed to mutations in the receptor binding domain of spike protein [9]. This necessitates the testing of as many individuals as possible to diagnose those infected with SARS-CoV-2 and more importantly to identify the asymptomatic carriers who may unknowingly infect a large population. SARS-CoV-2 is a singlestranded positive-sense RNA virus with approximately $29.9 \mathrm{~kb}$ genome size [10]. The capsid outside the genome is formed of nucleocapsid protein $(\mathrm{N})$ which is further enclosed by an envelope. Three types of structural proteins are associated with the envelope: spike protein (S), membrane protein $(\mathrm{M})$ and envelope protein $(\mathrm{E})$. Other than these four structural proteins (N, S, M and E) SARS$\mathrm{CoV}-2$ genome also encodes sixteen non-structural proteins (NSP1-16). RNA dependent RNA polymerase (RdRp) also known as NSP 12, plays an important role in multiplication of coronavirus [11]. In late 2020, a fast-spreading B.1.1.7 strain was reported which has mutation in spike protein and 56\% more transmissible than the earlier reported strain of SARS-CoV2 [12]. Another fast-spreading B.1.351 variant of SARS-CoV-2 was reported from South Africa. P.1, P.2 and P3 variants were reported from Brazil. B.1.427/B.1.429 variant was first identified in California. The first case of B.1.525 variant was reported in UK. B.1.526 variant was originated in New York. Recently in India, SARS-CoV-2 variants were reported that belongs to the B.1.617 lineage: B.1.617.1 and B.1.617.2 (https://www.who.int/en/activ ities/tracking-SARS-CoV-2-variants/). WHO keeps a close watch on the transmissibility and spreading of new variants of SARS-CoV-2. During late 2020, WHO categorized the emerging variants of SARS-CoV-2 as Variants of interest (VOIs) and Variants of concern (VOCs). The variants with increased transmissibility that can change epidemiology of COVID-19 and/or increased virulence that can reduce the effectiveness of vaccines, diagnosis, therapeutics, etc. are termed as Variants of interest (VOIs) whereas the variants that increase the severity of the disease and results in community transmission/ multiple COVID-19 cases/clusters, or has been detected in multiple countries are termed Variants of concern (VOCs). B.1.1.7 (Alpha), B.1.351 (Beta), P.1 (Gamma), B.1.617.2 (Delta) are presently grouped in VOCs, while B.1.427/B.1.429 (Epsilon), P.2 (Zeta), B.1.525 (Eta), P.3 (Theta), B.1.526 (Iota), B.1.617.1 (Kappa) are mentioned as VOIs (https://www.who.int/en/activities/trackingSARS-CoV-2-variants/).

Serological or nucleic acid detection based assays may be used for the diagnosis of COVID-19. Serological assays mostly depend on the detection of viral particles in nasal or throat swab samples by using antibodies against the spike protein. Such assays provide a quick diagnosis with minimalistic infrastructure and expertise [13, 14]. However, such rapid antigen tests suffer from a high false negative rate $[15,16]$. Hence nucleic acid based assays remain the popular choice [17].

Reverse transcription real-time PCR (rt-RT-PCR) employing the Taqman $^{\mathrm{TM}}$ chemistry for detection of viral RNA is considered the gold standard for diagnostic testing of individuals for COVID-19 [17]. A validated rt-RT-PCR assay for COVID-19 diagnosis was designed at Charité Institute of Virology in Berlin, Germany [18]. Similar assays have been described in many other countries and are commercially available through several companies [19]. This involves Taqman ${ }^{\mathrm{TM}}$ probe based assay for the E gene, followed by a Taqman ${ }^{\mathrm{TM}}$ assay for RdRp gene for confirmation. Hong Kong University developed a Taqman $^{\mathrm{TM}}$ probe based assay for the $\mathrm{N}$ gene followed by a confirmatory assay for Orf1b. United States Centres for Disease Control (US-CDC) has designed Taqman ${ }^{\mathrm{TM}} \mathrm{rt}$ RT-PCR using 3 primer-probe assays (N1, N2 and RP), which are assayed separately but simultaneously (https:// www.who.int/docs/default-source/coronaviruse/whoin houseassays.pdf).

Worldwide, the high demand for Taqman ${ }^{\mathrm{TM}}$ assays and other reagents required for the test has resulted in higher prices and shortages, especially for the developing countries with a large population [20]. Dye based rt-RT-PCR assay using SYBR Green I have been proposed by several research groups for the diagnosis of COVID-19 [21-24]. Next Generation Sequencing (NGS) based assay for testing hundreds to thousands of patient samples in parallel have also been proposed and are under development. Recently, one such NGS based assay for parallel testing of COVID-19 has been cleared for marketing by the United States Food and Drug Administration (US-FDA) under Emergency Use Authorization (EUA) (https://www.fda. 
gov/media/146933/download). Reverse Transcription Loop-Mediated Isothermal Amplification (RT-LAMP) is also a viable alternative for diagnostic detection of COVID-19 and has been proposed and developed by several researchers. RT-LAMP assays rely on conversion of viral RNA to cDNA, followed by target DNA amplification using a set of four to six primers, at a uniform temperature, without the requirement of temperature cycling. A large amount of target DNA is rapidly amplified in a LAMP reaction and can be detected using DNA binding dyes such as SYBR Green I or through changes in $\mathrm{pH}$, which can be detected visually or colorimetrically by using $\mathrm{pH}$ sensitive dyes $[25,26]$. RT-LAMP assays have been described for several human pathogenic viruses, including the Influenza viruses, Zika virus, Chikungunya virus, West Nile virus, etc. [27-30].

\section{Materials and methods}

\section{Collection of samples and isolation of viral RNA}

Naso-pharyngeal swabs were collected and stored in Viral Transport Medium (VTM) as per the standard procedures [31]. Total RNA was isolated from VTM using QIAamp Viral RNA Mini Kit (QIAGEN, Germany), following the manufacturer's instructions. RNA was quantified using the NanoDrop ${ }^{\mathrm{TM}}$ spectrophotometer (NanoDrop 2000c, Thermo Fisher Scientific, USA). Control human RNA for generating synthetic template of $\beta$-Actin was isolated from PANC-1 cell lines maintained in DMEM supplemented with $10 \%$ FBS and $1 \%$ penicillin-streptomycin, at $37{ }^{\circ} \mathrm{C}$ under $5 \% \mathrm{CO}_{2}$, as described earlier [32]. The quality and quantity of control RNA was assessed by running on $2 \%$ agarose gel and measuring optical density (OD) at $260 \mathrm{~nm}$ using NanoDrop ${ }^{\text {TM }}$ spec- $^{\text {s. }}$ trophotometer, respectively.

\section{Taqman $^{\text {TM }}$ rt-RT-PCR}

$5 \mu \mathrm{L}$ of viral RNA was added to a $20 \mu \mathrm{L}$ reaction mixture containing $12.5 \mu \mathrm{L}$ of $2 \mathrm{X}$ reaction mix, $1.5 \mu \mathrm{L}$ PrimerProbe mix, $0.5 \mu \mathrm{L}$ of Superscript ${ }^{\mathrm{TM}}$ III RT/Platinum ${ }^{\mathrm{TM}}$ Taq Mix (Thermo Fisher Scientific, USA) and $5.5 \mu \mathrm{L}$ nuclease free water. Reactions were carried out in 7500 Real-Time PCR (Applied Biosystems, Thermo Fisher Scientific, USA) or Rotor-Gene Q 2Plex (QIAGEN, Germany) with the following thermal cycling conditions: incubation at $50{ }^{\circ} \mathrm{C}$ for $30 \mathrm{~min}, 95^{\circ} \mathrm{C}$ for $3 \mathrm{~min}$ followed by 45 two-step cycles of $95{ }^{\circ} \mathrm{C}$ for $15 \mathrm{~s}$ and $58{ }^{\circ} \mathrm{C}$ for $30 \mathrm{~s}$, with data collection in green channel at the annealing-extension step. A positive viral template control (VTC) and a negative no template control (NTC) assay were carried out in each run. For VTC, $1.5 \mu \mathrm{L}$ of control templates (positive control kits obtained from Integrated DNA Technologies, USA) were used, while for NTC, nuclease free water was used instead of template.

\section{Reverse transcription loop-mediated isothermal amplification}

cDNA was synthesized in a $10 \mu \mathrm{L}$ RT reaction, by using ImProm-II ${ }^{\mathrm{TM}}$ Reverse Transcription System (Promega, USA) with random hexamers and using 10-40 ng of viral RNA and control human RNA (PANC-1) as template, following manufacturer's instructions. cDNA was used immediately for LAMP reaction or stored at $-40{ }^{\circ} \mathrm{C}$ until further use. cDNA was also used for generating synthetic templates for viral genes as well as for control human $\beta$-Actin gene. $10 \mu \mathrm{L}$ LAMP reaction contained $1 \mu \mathrm{L} \mathrm{cDNA}$ or $1-2 \mathrm{ng}$ of synthetic template, $1 \mu \mathrm{L}$ of $10 \mathrm{X}$ LAMP primer mix, $1 \mu \mathrm{L}$ of $2 \mathrm{mM}$ dNTP, $1 \mu \mathrm{L}$ of $10 \mathrm{X}$ buffer, $0.3-1 \mu \mathrm{L}(2.4-10 \mathrm{U})$ of LAMP DNA Polymerase and nuclease free water to make up the reaction volume. Additionally, $\mathrm{MgSO}_{4}$ or $\mathrm{MgCl}_{2}$, were also used in reactions with some LAMP Polymerases and the optimized conditions are discussed in results section. Reactions were always set in a cold block. Reactions were incubated at uniform temperature of $50{ }^{\circ} \mathrm{C}$ to $60{ }^{\circ} \mathrm{C}$, depending on the DNA polymerase enzyme used for LAMP reaction. Quantities of the DNA oligos used in 10X LAMP primer mix were optimized for each of the LAMP primer set and have been described in the results section.

\section{Visualization, densitometry and statistical analysis}

At the end of LAMP reaction, an appropriate quantity of SYBR Green 1 dye (0.2-1 $\mu \mathrm{L}$ of 1:100 dilution in DMSO) was added and the tubes were visually examined under UV light and photographed using a $8 \mathrm{MP}$ auto-focus digital camera with ISO $1600-3200$ and exposure $1 / 15$ to $1 / 30 \mathrm{~s}$. Integrated density of the fluorescence in the reaction tubes was measured using the measurement tool in Photoshop CS3 extended (Adobe, USA) and for calculation integrated density of NTC was subtracted from the integrated density of samples. For the measurement of densitometric ratios, the region of interest (ROI) was marked using the 'lasso tool.' The ROI was marked in the area of tubes where reaction mixture was present and green fluorescence appeared. The size and shape of the ROI was kept constant for all tubes, including the NTC. Three technical replicates were used for analysis. Average and standard deviation calculations as well as plotting of graphs were done in MS Office Excel 2007 (Microsoft Corporation, USA). The reactions of RT-LAMP assays were also checked on $2 \%$ agarose gel for the presence of ladder pattern.

\section{Computational methods}

Sequences of SARS-CoV2 and other betacoronaviruses were downloaded from the NCBI GenBank database (www.ncbi.nlm.nih.gov). Accession numbers of 
sequences are available in Sheet 1 of Additional file 1 . Alignments were done using CLC Genomics Workbench 10 (Qiagen, Germany). LAMP primers were designed using PrimerExplorer V5 (https://primerexplorer.jp/e/).

\section{Results \\ LAMP primers}

Four to six lamp primers were designed (Fig. 1a) for each of the seven loci (Fig. 1b, Table 1) from the viral genome (SARS-CoV2 reference genome sequence NC_045512.2) and two loci in the human $\beta$-actin gene (NM_001101.5). In order to ensure that the regions used for designing the LAMP primers are specific to SARS-CoV2, these sequence regions were analyzed by BLASTN (https:// blast.ncbi.nlm.nih.gov). For this purpose all the reference sequences (NCBI GenBank RefSeq) that were available for betacoronaviruses (Sheet 1 of Additional file 1), including that of SARS-CoV2, were downloaded and a local BLAST database was created. Selected sequence regions of the SARS-CoV2, from where the LAMP primers were designed, were compared with the sequences of other betacoronaviruses (Additional file 1). As expected the second top hit for all primer binding regions was the SARS-CoV (Additional file 1). However, the percentage identity was never more than 93\%. Further, alignments of the selected seven loci of SARS-CoV2, with the closest BLAST matches in the betacoronavirus genomes, showed significant differences in the primer binding sites. These alignments also suggest that $\mathrm{L} 1, \mathrm{RdRp}$ and $\mathrm{N} 1$ primer sets can discriminate between SARS-CoV and SARS-CoV2, due to significant sequence differences in binding sites of at least one or both of the outer primers (F3 and B3), that are critical for LAMP amplification. On the other hand, conservation of primer binding sites among the variants of SARS-CoV2 is vital for its detection. 284 complete genomes of SARS-CoV2 from India and 5642 genomes worldwide were surveyed. Sequences for the selected seven loci (Table 1, Fig. 1b), where LAMP primer were

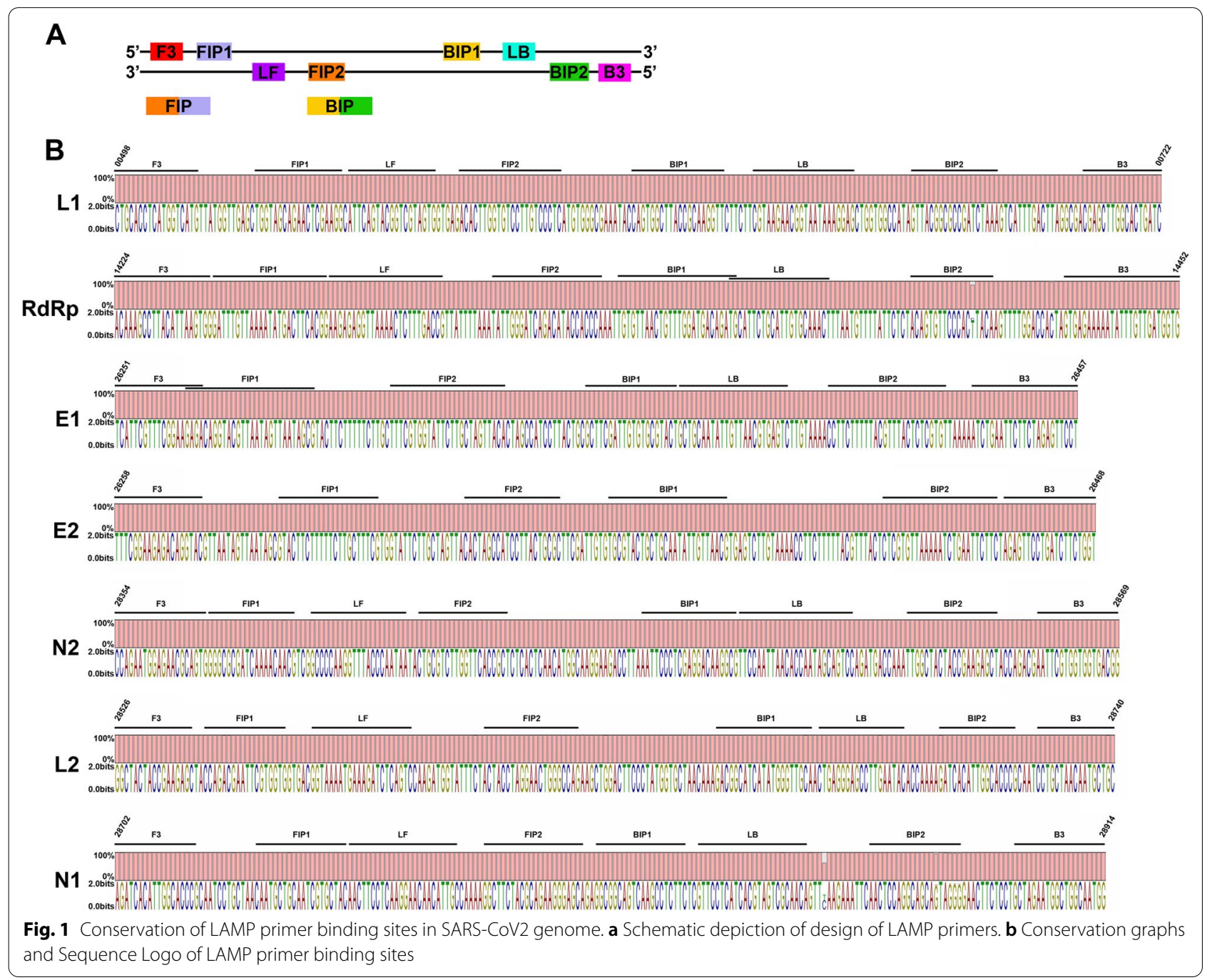


Table 1 LAMP primer sequences

\begin{tabular}{|c|c|c|c|c|c|c|c|}
\hline \multirow[t]{2}{*}{ Gene } & \multirow[t]{2}{*}{ Protein } & \multicolumn{2}{|c|}{$\begin{array}{l}\text { Genomic } \\
\text { coordinates }\end{array}$} & \multirow{2}{*}{$\begin{array}{l}\text { Length } \\
\text { of } \\
\text { region }\end{array}$} & \multirow{2}{*}{$\begin{array}{l}\text { Name of } \\
\text { primer } \\
\text { set }\end{array}$} & \multirow[t]{2}{*}{ Name of primer } & \multirow[t]{2}{*}{ Sequence } \\
\hline & & Start & End & & & & \\
\hline \multirow[t]{6}{*}{ ORF1AB } & NSP1 & 498 & 722 & 225 & L1 & L1-F3 & CTGCACCTCATGGTCATG \\
\hline & & & & & & L1-B3 & GATCAGTGCCAAGCTCG \\
\hline & & & & & & $\mathrm{L} 1-\mathrm{Fl}$ & GAGGGACAAGGACACCAAGTGTGGTAGCAGAACTCGAAG \\
\hline & & & & & & L1-C-BI & CAGTGGCTTACCGCAAGGTTTTAGATCGGCGCCGTAAC \\
\hline & & & & & & L1-LF & CACTACGACCGTACTGAAT \\
\hline & & & & & & L1-LB & CGTAAGAACGGTAATAAAGGAG \\
\hline \multirow[t]{6}{*}{ ORF1AB } & $\mathrm{RdRP}$ & 14,224 & 14,452 & 229 & $\mathrm{RdRp}$ & rdrp1F3 & ACAAAGCCTTACATTAAGTGG \\
\hline & & & & & & rdrp1B3 & CACCATCAACAAATATTTTTCTCAC \\
\hline & & & & & & rdrp1FIP & $\begin{array}{l}\text { TGGGTGGTATGTCTGATCCCAATAGATTTGTTAAAATATGAC } \\
\text { TTCACGG }\end{array}$ \\
\hline & & & & & & rdrp1BIP & TGTGTTAACTGTTTGGATGACAGATGTAGGTGGGAACACTGT \\
\hline & & & & & & rdrp1LF & CGGTCAAAGAGTTTTAACCTCTCTT \\
\hline & & & & & & rdrp1LB & TGCATTCTGCATTGTGCAAACT \\
\hline \multirow[t]{5}{*}{$\mathrm{E}$} & $\mathrm{E}$ & 26,251 & 26,457 & 207 & E1 & e1F3 & TCATTCGTTTCGGAAGAGA \\
\hline & & & & & & e1B3 & AGGAACTCTAGAAGAATTCAGAT \\
\hline & & & & & & e1FIP & $\begin{array}{l}\text { TGTAACTAGCAAGAATACCACGAAACAGGTACGTTAATAGTT } \\
\text { AATAGCG }\end{array}$ \\
\hline & & & & & & e1BIP & $\begin{array}{l}\text { GCTTCGATTGTGTGCGTACTCGAGAGTAAACGTAAAAAG } \\
\text { AAGG }\end{array}$ \\
\hline & & & & & & e1LB & GCTGCAATATTGTTAACGTGAGTC \\
\hline \multirow[t]{4}{*}{$\mathrm{E}$} & $\mathrm{E}$ & 26,258 & 26,468 & 211 & E2 & $\mathrm{e} 2 \mathrm{~F} 3$ & TTTCGGAAGAGACAGGTAC \\
\hline & & & & & & e2B3 & ACCAGAAGATCAGGAACTCT \\
\hline & & & & & & e2FIP & $\begin{array}{l}\text { GCGCAGTAAGGATGGCTAGTGGTACTTCTTTTTCTTGCT } \\
\text { TTCG }\end{array}$ \\
\hline & & & & & & e2BIP & $\begin{array}{l}\text { TGCGTACTGCTGCAATATTGTTAACGAAGAATTCAGATTTTTT } \\
\text { AACACGAG }\end{array}$ \\
\hline \multirow[t]{6}{*}{$\mathrm{N}$} & N & 28,354 & 28,569 & 216 & $\mathrm{~N} 2$ & $\mathrm{n} 2 \mathrm{~F} 3$ & CCAGAATGGAGAACGCAGTG \\
\hline & & & & & & n2B3 & CCGTCACCACCACGAATT \\
\hline & & & & & & $\mathrm{n} 2 \mathrm{FIP}$ & AGCGGTGAACCAAGACGCAGGGCGCGATCAAAACAACG \\
\hline & & & & & & $\mathrm{n} 2 \mathrm{BIP}$ & AATTCCCTCGAGGACAAGGCGAGCTCTTCGGTAGTAGCCAA \\
\hline & & & & & & $\mathrm{n} 2 \mathrm{LF}$ & TTATTGGGTAAACCTTGGGGC \\
\hline & & & & & & $\mathrm{n} 2 \mathrm{LB}$ & TTCCAATTAACACCAATAGCAGTCC \\
\hline \multirow[t]{6}{*}{ N } & N & 28,526 & 28,740 & 215 & L2 & L2-F3 & GGCTACTACCGAAGAGC \\
\hline & & & & & & L2-B3 & GCAGCATTGTTAGCAGG \\
\hline & & & & & & $\mathrm{L} 2-\mathrm{Fl}$ & CTGGCCCAGTTCCTAGGTAGTCCAGACGAATTCGTGGTG \\
\hline & & & & & & $\mathrm{L} 2-\mathrm{Bl}$ & GACGGCATCATATGGGTTGCACGGGTGCCAATGTGATC \\
\hline & & & & & & L2-LF & GACTGAGATCTTTCATTTTACC \\
\hline & & & & & & L2-LB & CTGAGGGAGCCTTGAATAC \\
\hline \multirow[t]{6}{*}{ N } & $\mathrm{N}$ & 28,702 & 28,914 & 213 & N1 & n1F3 & AGATCACATTGGCACCCG \\
\hline & & & & & & n1B3 & CCATTGCCAGCCATTCTAGC \\
\hline & & & & & & $\mathrm{n} 1 \mathrm{FIP}$ & TGCTCCCTTCTGCGTAGAAGCCAATGCTGCAATCGTGCTAC \\
\hline & & & & & & $\mathrm{n} 1 \mathrm{BIP}$ & GGCGGCAGTCAAGCCTCTTCCCTACTGCTGCCTGGAGTT \\
\hline & & & & & & n1LF & GCAATGTTGTTCCTTGAGGAAGTT \\
\hline & & & & & & $\mathrm{n} 1 \mathrm{LB}$ & GTTCCTCATCACGTAGTCGCAACA \\
\hline \multirow[t]{5}{*}{ Human $\beta$-actin } & Human $\beta$-actin & 585 & 787 & 203 & ACTB1 & hACTBF3 & GCGCGGCTACAGCTTCA \\
\hline & & & & & & hACTBB3 & GGAAGAGTGCCTCAGGGC \\
\hline & & & & & & hACTBFIP & AAGTCCAGGGCGACGTAGCACCGGCCGAGCGGGAAAT \\
\hline & & & & & & hACTBBIP & GAGATGGCCACGGCTGCTTCCATTGCCAATGGTGATGACCT \\
\hline & & & & & & hACTBLF & TTCTCCTTAATGTCACGCACG \\
\hline
\end{tabular}


Table 1 (continued)

\begin{tabular}{|c|c|c|c|c|c|c|c|}
\hline \multirow[t]{2}{*}{ Gene } & \multirow[t]{2}{*}{ Protein } & \multicolumn{2}{|c|}{$\begin{array}{l}\text { Genomic } \\
\text { coordinates }\end{array}$} & \multirow{2}{*}{$\begin{array}{l}\text { Length } \\
\text { of } \\
\text { region }\end{array}$} & \multirow{2}{*}{$\begin{array}{l}\text { Name of } \\
\text { primer } \\
\text { set }\end{array}$} & \multirow[t]{2}{*}{ Name of primer } & \multirow[t]{2}{*}{ Sequence } \\
\hline & & Start & End & & & & \\
\hline & & & & & & hACTBLB & CCCTGGAGAAGAGCTACGAG \\
\hline \multirow[t]{5}{*}{ Human $\beta$-actin } & Human $\beta$-actin & 197 & 390 & 194 & ACTB2 & hACTB2F3 & CCCTGAAGTACCCCATCGA \\
\hline & & & & & & hACTB2B3 & TGGGGTGTTGAAGGTCTCAA \\
\hline & & & & & & hACTB2FIP & AGCCACACGCAGCTCATTGTAGCACGGCATCGTCACCAAC \\
\hline & & & & & & hACTB2BIP & AGCACCCCGTGCTGCTGAGTCATCTTCTCGCGGTTGG \\
\hline & & & & & & hACTB2LF & AGATTTTCTCCATGTCGTCCCA \\
\hline
\end{tabular}

designed, were extracted from the complete genomes and multiple sequence alignments were carried out for each region. In L1 region, although variants were observed in 54 out of 225 nucleotides in the 5642 completed SARS$\mathrm{CoV} 2$ genomes; minimum conservation at any nucleotide position was $99.5 \%$ (Table 2). Results from similar analysis with other selected loci from SARS-CoV2 are summarized in Table 2. Nearly 1000 SARS-CoV2 genomes were sequenced from India, at the time of the study and the sequence variants and their percentages are available (http://data.ccmb.res.in/gear19/variants). These variants were mapped onto the selected sequence loci from where LAMP primers were designed (Additional file 2). As may be observed from the conservation graphs (Fig. 1b), multiple sequence alignments and mapping of identified sequence variants (Additional file 2), the primer binding sites were conserved in the selected loci. The minimum percentage of conservation in variant nucleotides in the L1 and L2 primer binding sites was 99\% (Table 2).

\section{Evaluation of DNA polymerases for LAMP}

In order to test LAMP primers, synthetic positive templates were prepared (Fig. 2a). Viral RNA or control human RNA were reverse transcribed with random hexamers, as described earlier [33]. Outer primers (F3 and
B3; Fig. 1a) from each of the LAMP primer set (Table 1) were used for amplifying the target regions using cDNA as template. The amplified products were purified through gel elution and either used directly or cloned in PCR cloning vector and used as positive control template in LAMP reactions. Synthetic templates from viral loci were prepared from viral RNA while synthetic templates for $\beta$-actin were prepared from control human RNA. Five different DNA polymerases (Bst LF, Bst 2.0, Bst 3.0, Bsm and Klenow) were tested for LAMP and reaction conditions were optimized (Additional file 3). A positive LAMP reaction, identified by green fluorescence under the UV light, resulted when a synthetic positive control template was used, while the no-template-controls (NTC) lacked the fluorescence (Fig. 2b). This was further confirmed by electrophoresing the amplicons on an agarose gel, where only the positive LAMP reaction resulted in the classical ladder pattern (Fig. 2c). The fluorescence of the reaction tubes in Fig. $2 b$ were analysed through densitometry. Densitometric analysis of fluorescence values showed that Klenow gave the best result (Fig. 2d).

\section{Evaluation of LAMP primer sets}

Primer sets were tested with synthetic templates (Fig. 3) as well as patient samples using LAMP assay (Fig. 4).

Table 2 Conservation of LAMP primer binding sites in genomes of SARS-CoV2

\begin{tabular}{|c|c|c|c|c|c|}
\hline \multirow{2}{*}{$\begin{array}{l}\text { Locus (primer } \\
\text { set) }\end{array}$} & \multirow[t]{2}{*}{ Length } & \multicolumn{2}{|c|}{ Completed genomes worldwide (5642 sequences) } & \multicolumn{2}{|c|}{ Completed Genomes from India (284 sequences) } \\
\hline & & $\begin{array}{l}\text { Number of variant } \\
\text { nucleotides }\end{array}$ & $\begin{array}{l}\text { Minimum conservation in } \\
\text { variant nucleotides }(\%)\end{array}$ & $\begin{array}{l}\text { Number of variant } \\
\text { nucleotides }\end{array}$ & $\begin{array}{l}\text { Minimum conservation } \\
\text { in variant nucleotides } \\
(\%)\end{array}$ \\
\hline L1 & 225 & 54 & 99.5 & 5 & 99.6 \\
\hline $\operatorname{RdRp}$ & 229 & 24 & 64.2 & 4 & 87.4 \\
\hline E1 & 207 & 8 & 99.8 & 1 & 99.7 \\
\hline E2 & 211 & 7 & 99.9 & 1 & 99.7 \\
\hline N2 & 216 & 6 & 99.3 & 4 & 99.6 \\
\hline L2 & 215 & 14 & 99.1 & 8 & 99.3 \\
\hline N1 & 213 & 41 & 91 & 11 & 64 \\
\hline
\end{tabular}




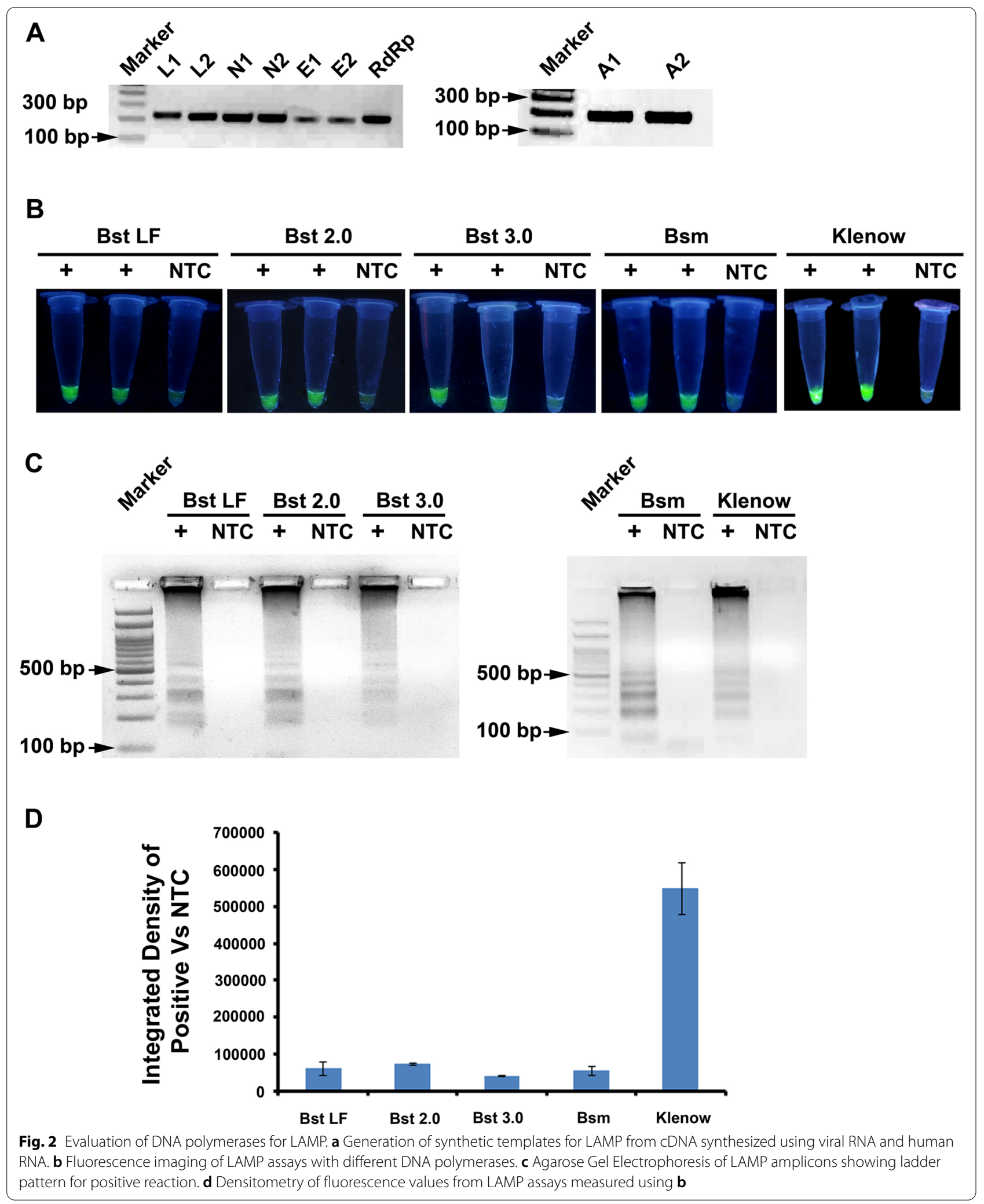




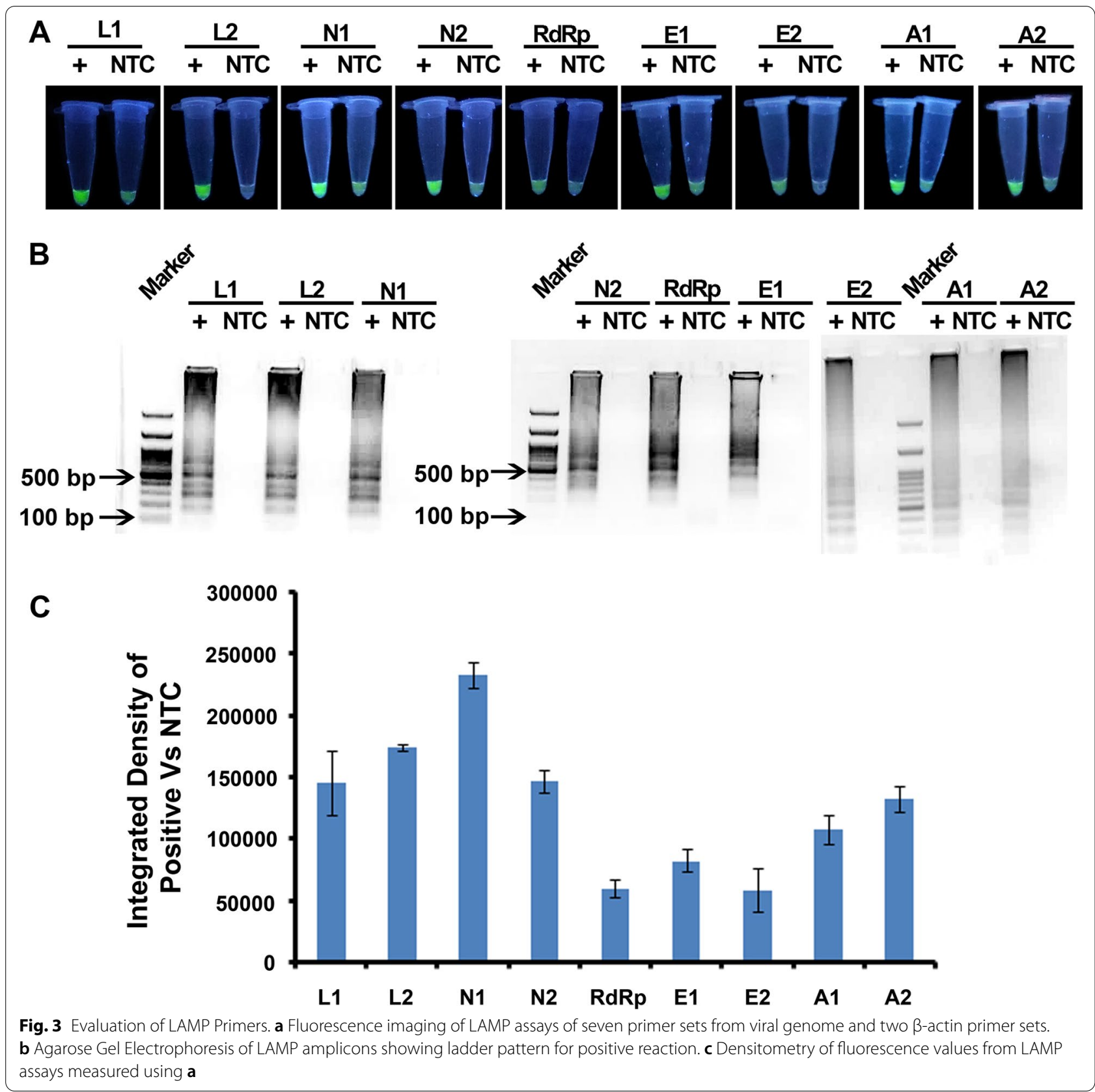

With the synthetic templates, the green fluorescence that appeared in reactions with primer sets L1, N2, L2 and $\mathrm{N} 1$ resulted in better contrast between the positive reaction and NTC (Fig. 3a), as verified through densitometry of reaction tubes (Fig. $3 \mathrm{c}$ ). Further, the amplicons were electrophoresed on a $2 \%$ agarose gel and only the positive reactions resulted in a ladder pattern, while the NTCs did not show any detectable amplicons. In order to further test the discriminating efficiency of the primers, the primers that fared well with synthetic templates were evaluated with patient samples. With patient samples, the L1 primer set resulted in one false positive and one of the patient sample (P-2) resulted in only a mild fluorescence (Fig. 4a). N1, N2 and L2 primer sets appeared to have the best contrast between the COVID-19 positive and negative samples as may be observed from the photographs and densitometric ratios (Fig. 4a, b). In view of better discrimination between SARS-CoV2 and other related viruses, L1 was chosen as one of the primer sets for final validation of RT-LAMP assay on a different and more number of patient samples. Additionally, N1 or L2 primer sets were chosen for second assay, because of 


\section{L1}
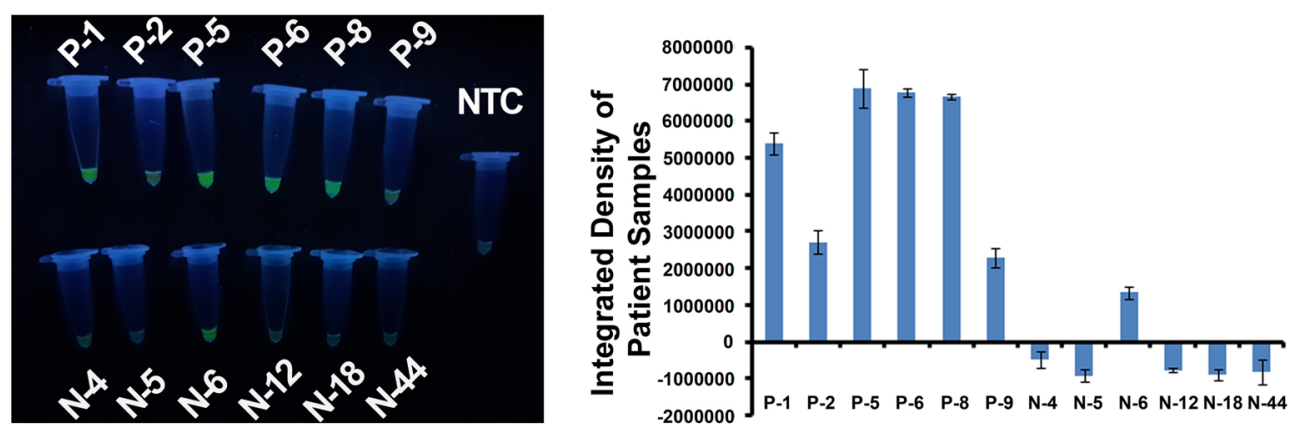

L2
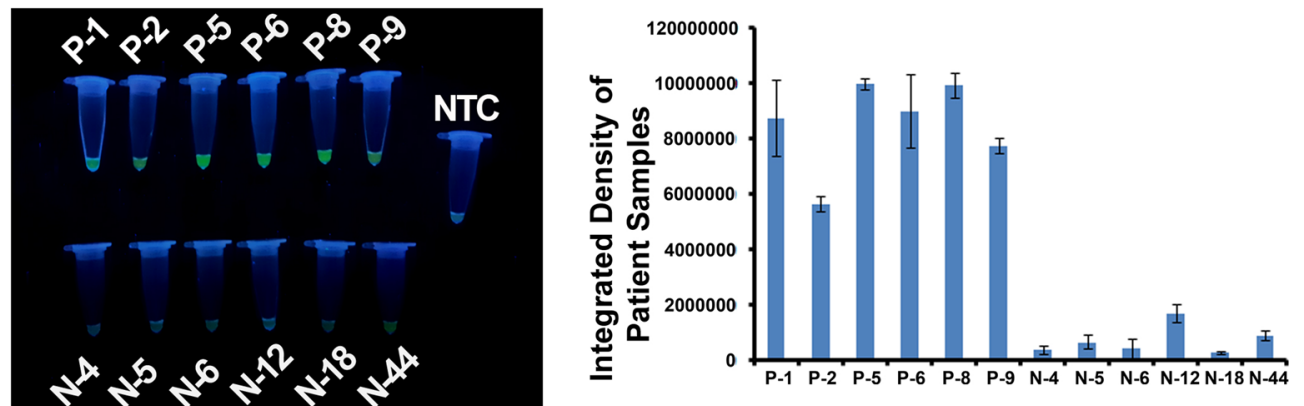

N1
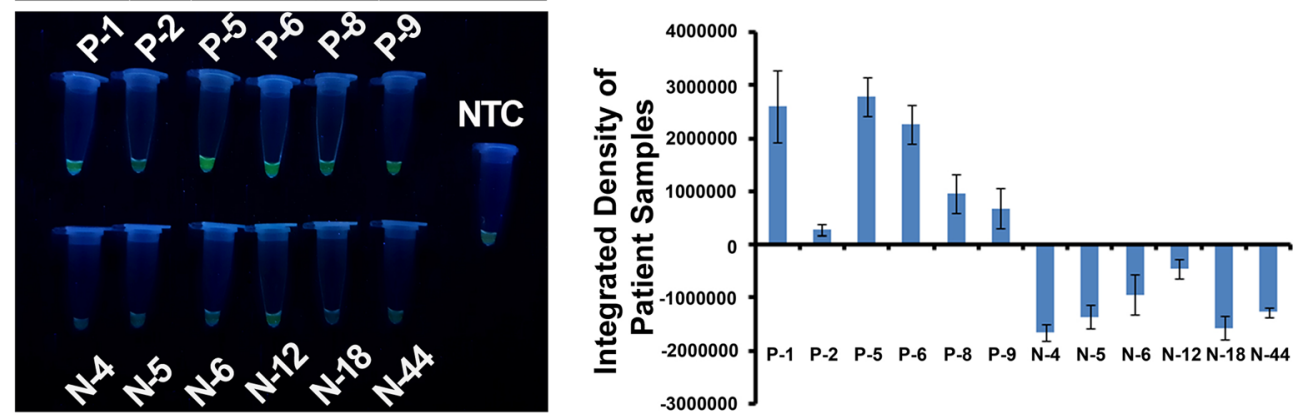

N2
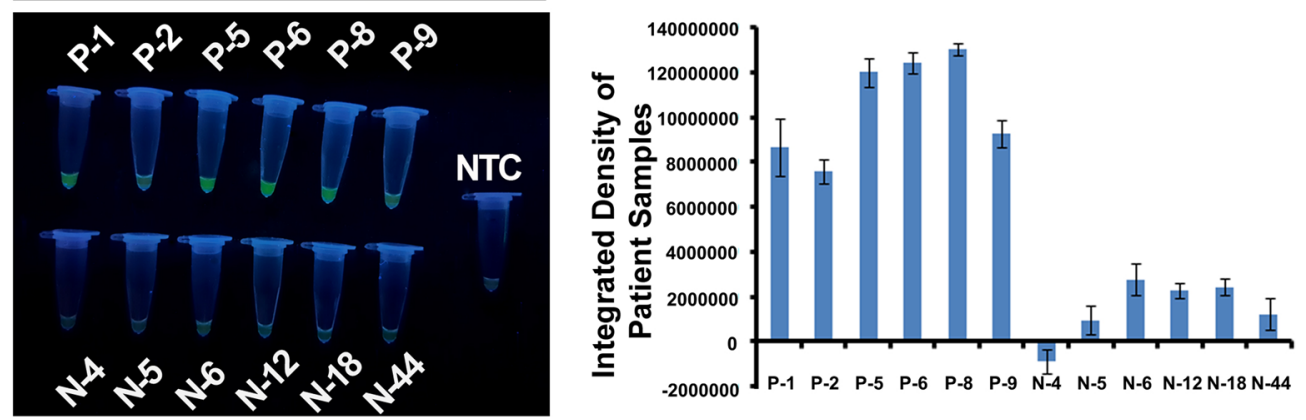

A1
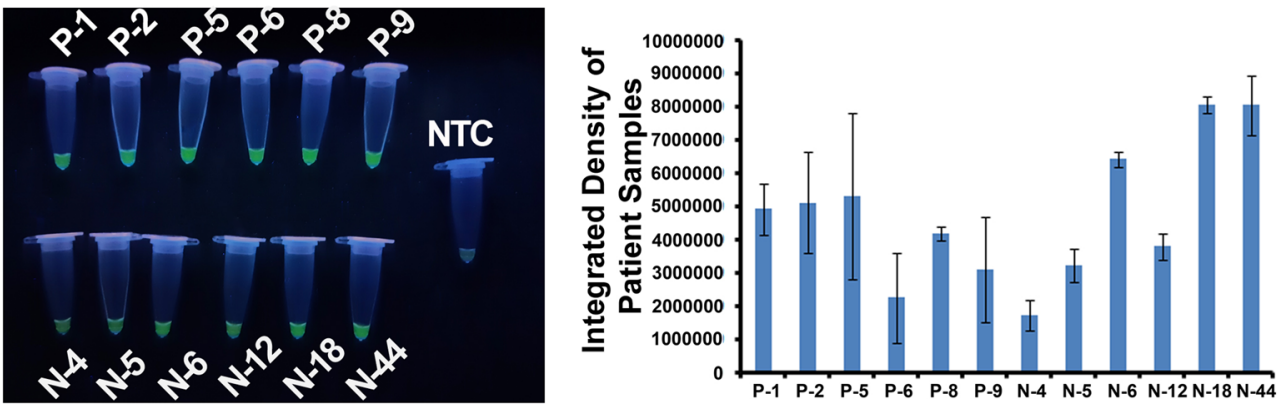

Fig. 4 Evaluation of LAMP Primers ( $L 1, L 2, N 1, N 2$ and $A 1$ primers sets) with patient samples 
better contrast between the positive and negative samples and since it did not result in any false negative or false positive. Two loci test employing a combination of $\mathrm{L} 1$ and L2 primers or L1 and N1 primers would thus provide a good resolution between the COVID-19 positive and negative samples. A1 and A2 primer sets were used for $\beta$-Actin human control gene. A1 primers set appeared to have better contrast than A2 primer set.

\section{Conservation of primer binding sites in SARS-CoV-2 variants}

Analysis was carried out, in order to assess the conservation of primer binding sites and suitability of our LAMP assay for all the WHO notified VOC and VOI of SARS$\mathrm{CoV}-2$. First 200 sequences of SARS-CoV-2 variants were downloaded from NCBI GenBank. For three variants (B.1.617.1, B.1.617.2 and P.3) lesser than 200 sequences were available in GenBank, hence all were downloaded. Accession numbers of the sequences are available in Additional file 1. The region of genome where L1 and L2 primers were designed was extracted from the complete genomes and multiple sequence alignments were carried out for each region. Only few nucleotides (marked with a star) showed a mismatch in a fraction of sequences, as may be observed in sequence logos generated from the alignments. It was found that the primer binding sites were strongly conserved in all the WHO notified VOC and VOI of SARS-CoV-2 (Additional file 4).

\section{Validation of RT-LAMP assay}

Taqman $^{\text {TM }}$ rt-RT-PCR was carried out using the USCDC protocol primers $\mathrm{N} 1$ and $\mathrm{N} 2$ on 22 patient samples. RT-LAMP assay was carried out in a double blind manner, using the primer sets L1 and L2 (Table 3). The negatives in either RT-LAMP or rt-RT-PCR are marked with light green color and positives are marked with light red color. For 18 samples, out of 22, the results of RT-LAMP, matched between the L1 and L2 primer sets. For the remaining four samples, where there was a mismatch, a COVID-19 negative call was made on the basis of RT-LAMP assay. Only in one out of these four, the sample gave a positive result with rt-RT-PCR. In total, there were three false negatives in RT-LAMP using the L1 and L2 primer sets, which could be due to low viral load. Optimized RT-LAMP assay protocol was independently verified at a second site at Mumbai by Reliance Industries (RIL), on a much larger set of samples and the result statistics tallied with the data reported here. On other site RIL also carried out Taqman ${ }^{\mathrm{TM}}$ rt-RT-PCR on 148 patient samples. RT-LAMP assay was carried out in a double blind manner, using L1 and N1 primer sets (Additional file 5). The negatives in either RT-LAMP or rt-RTPCR are marked with light green color and positives are marked with light red color. For 132 samples, out of 148, the results of RT-LAMP, matched with Taqman ${ }^{\mathrm{TM}}$ rt-RTPCR results.

\section{Discussion}

As per several reports and speculations, increasing the number of tests may show a significantly higher prevalence of infection [34]. Detection of infected individuals is critical to circumvent the spread of disease and effectuation of containment measures [35, 36]. The problem is accentuated by the fact that a large percentage of infected individuals may not show any symptoms or signs of only a mild infection [8], which may go undetected, especially in rural areas with paucity of medical facilities. Further, in developing and underdeveloped countries with limited resources and State funded testing, this involves a huge cost and burden to the economy [37, 38]. At several places, the expertise and high end instrumentation required for carrying out rt-RT-PCR assays may not be readily available, leading to higher costs in transportation of samples and delays in getting the test results. Hence, cheaper methods for testing individuals, which are also less resource intensive in terms of instrumentation, are always sought after. RT-LAMP can be used as a viable, cheaper and less resource intensive method for testing of COVID-19. RT-LAMP protocols have been developed for the detection of many other viruses, including influenza strains, Zika, Japanese encephalitis, Chikungunya, West Nile virus, etc. [27-30]. Several researchers have also developed RT-LAMP protocols for the detection of COVID-19 [39-42]. Here, we have developed, optimized and validated a two step RT-LAMP method for detection of COVID-19.

A detailed survey of genomic sequences of SARS-CoV2 and other betacoronavirues was carried out and LAMP primers were designed (Fig. 1) in such a manner that they should be able to distinguish SARS-CoV2 from very similar SARS-CoV. For this purpose all the available genomic sequences in the betacoronavirus group were downloaded from NCBI GenBank and primer binding regions were extracted and aligned (Additional file 1). Among the 19 available genomes, the second top BLAST hit for the primer binding sites was in SARS-CoV genome. This was expected considering that both these viruses have jumped from bats to humans and share an overall $80 \%$ nucleotide sequence similarity with about $94.6 \%$ similarity at protein level, especially in the genes involved in the replication of virus $[43,44]$. MERS is another betacoronaviruses that may still be circulating in the population $[45,46]$; however the sequence similarity, atleast in our LAMP primer binding sites was very low. It is noteworthy, that atleast one of the outer primers (F3 and B3) of the L1, N1 and RdRp primer set, shows significant 
Table 3 Validation of RT-LAMP assay

\begin{tabular}{|c|c|c|c|c|c|c|}
\hline $\begin{array}{l}\text { Sample } \\
\text { name }\end{array}$ & ACTB1 & $\mathrm{L} 1$ & L2 & Result from RT-LAMP & $\begin{array}{l}\text { Result from } \\
\text { rt-RT-PCR }\end{array}$ & $\begin{array}{c}\text { Match between } \\
\text { RT-LAMP \& rt-RT- } \\
\text { PCR }\end{array}$ \\
\hline KQC01 & + & + & + & COVID +ve & COVID +ve & Match \\
\hline KQC02 & + & - & - & COVID -ve & COVID +ve & Mis-Match \\
\hline KQC03 & + & + & + & COVID +ve & COVID +ve & Match \\
\hline KQC04 & + & + & + & COVID +ve & COVID +ve & Match \\
\hline KQC05 & + & + & + & COVID +ve & COVID +ve & Match \\
\hline KQC06 & + & - & - & COVID -ve & COVID -ve & Match \\
\hline KQC07 & + & + & + & COVID +ve & COVID +ve & Match \\
\hline KQC08 & + & - & - & COVID -ve & COVID +ve & Mis-Match \\
\hline KQC09 & + & - & - & COVID -ve & COVID -ve & Match \\
\hline KQC10 & + & - & - & COVID -ve & COVID -ve & Match \\
\hline KQC11 & + & - & - & COVID -ve & COVID -ve & Match \\
\hline KQC12 & + & - & - & COVID -ve & COVID -ve & Match \\
\hline KQC13 & + & - & - & COVID -ve & COVID -ve & Match \\
\hline KQC14 & + & - & - & COVID -ve & COVID -ve & Match \\
\hline KQC15 & + & - & + & COVID -ve & COVID -ve & Match \\
\hline KQC16 & + & - & - & COVID -ve & COVID -ve & Match \\
\hline KQC17 & + & - & - & COVID -ve & COVID -ve & Match \\
\hline KQC18 & + & + & - & COVID -ve & COVID -ve & Match \\
\hline KQC19 & + & - & + & COVID -ve & COVID -ve & Match \\
\hline KQC20 & + & - & + & COVID -ve & COVID +ve & Mis-Match \\
\hline KQC21 & + & - & - & COVID -ve & COVID -ve & Match \\
\hline KQC22 & + & - & - & COVID -ve & COVID -ve & Match \\
\hline
\end{tabular}

differences at the primer binding sites in SARS-CoV2 and closely related SARS-CoV. This is important for accurate testing of COVID-19 and discrimination from SARS$\mathrm{CoV}$ infection. We analyzed the 5642 complete SARS$\mathrm{CoV} 2$ genomes and found that primer binding sites of our LAMP primers are well conserved (Fig. 1, Table 2). Further, L1 primer set lies in NSP1 gene, which was recently shown to be highly expressed in nasopharyngeal and saliva samples from more than 100 patients [47]. L1 and L2 primer binding sites are conserved in all the
WHO notified VOC and VOI. Thus, our RT-LAMP assay may be used for detection of SARS-CoV-2, including the presently globally dominant Delta variant.

Several enzymes that are capable of strand displacement activity have been used in LAMP reactions [4851]. In order to test which of these DNA polymerases works best and is easier and relatively inexpensive, for our assays, we tested the wild type enzymes: Klenow fragment, Bsm large fragment, Bst large fragment as well as engineered variants such as Bst 2.0 and Bst 3.0 
(Fig. 2, Additional file 3) that have been shown to have improved speed of reaction and ability to withstand inhibitors that are commonly found in biological specimens (https://international.neb.com/products/m0374bst-3-0-dna-polymerase). Klenow fragment had a compulsory requirement of denaturation of template at high temperature followed by quick chill, before adding the enzyme, for a successful LAMP reaction (data not shown). All other enzymes did not have this requirement. Further, all other enzymes except Bst 3.0 required addition of $\mathrm{Mg}++$ ions as $\mathrm{MgCl}_{2}$ (Klenow) or $\mathrm{MgSO}_{4}$ (Bsm, Bst and Bst 2.0) for efficient LAMP amplification (Additional file 3). The time required for LAMP amplification was highest for Klenow and lowest when Bst 3.0 was used as LAMP polymerase. Using higher temperature for LAMP reaction helps in avoiding non specific amplification, hence it is desirable. Bst 2.0 and Bst 3.0 worked efficiently at higher temperatures as compared to Klenow which worked at $50{ }^{\circ} \mathrm{C}$, hence all further experiments were carried out with Bst 3.0 polymerase.

Detection of amplification in RT-LAMP reaction may be carried out by a realtime PCR, electrophoresing the amplicons on an agorose gel, colorimetric detection of $\mathrm{pH}$ changes during the amplification or by addition of DNA binding fluorescent dyes in the LAMP reaction [25, 26, 28]. Several fluorescent dyes such as SYBR Green I, Eva Green, SYTO 9, etc. have been used for this purpose. We have used SYBR Green I in our assays. For Bst 2.0 and Bst 3.0 addition of only $0.2 \mu \mathrm{L}$ of 1:100 diluted SYBR Green I dye was found to be sufficient for naked eye detection of successful LAMP amplification (Fig. 2).

On the basis of better results and conservation of primer binding sites in all VOC and VOI of SARS$\mathrm{CoV}-2$, the L1 and L2 primer set were selected for validation on patient samples, in a double blind study. We found that there were three false negatives in RTLAMP assay when compared to the Taqman ${ }^{\mathrm{TM}}$ rt-RTPCR assay (Table 3 ). In the study carried out by RIL on validation of RT-LAMP assay, it was observed that out of 148 patient samples, the results of 15 samples were not matching with $\mathrm{Taqman}^{\mathrm{TM}}$ rt-RT-PCR assay. This could be due to lower viral load in these samples. Recently it was shown that on 8th day after exposure and establishment of SARS-CoV2 infection, there was $38 \%$ chance of false negative detection in rt-RT-PCR test, which was minimal. The percentage of false negative detection was nearly $100 \%$ on day 1 and reduced to $67 \%$ by day 4 . The issue of false negative may be overcome by testing the individuals at least two times at an interval of 3-4 days [52].

\section{Conclusion}

We found that our RT-LAMP assay was $89.2 \%$ accurate when compared to the current gold standard Taqman ${ }^{\mathrm{TM}}$ rt-RT-PCR assay. We further conclude that our assay may be used for detection of all current WHO notified VOC and VOI of SARS-CoV-2. It is also pertinent to mention that RT-LAMP assay can be used as a feasible, low cost, less resource, alternative molecular diagnostic test for COVID-19. It may be used as a primary assay as well as for routine surveillance in schools, offices and other organizations, especially in rural or far-flung areas where elaborate instrumentation facilities do not exist.

\section{Abbreviations}

SARS-CoV2: Severe Acute Respiratory Syndrome Coronavirus 2; COVID-19: Coronavirus disease 2019; VOC: Variants of concern; VOI: Variants of interest; RT-LAMP: Reverse Transcription Loop-mediated isothermal AMPlification; MERS: Middle East Respiratory Syndrome; rt-RT-PCR: Reverse transcription real-time PCR; RdRp: RNA-dependent RNA polymerase; E: Envelope protein; N: Nucleocapsid protein; US-CDC: United States Centres for Disease Control; NGS: Next generation sequencing; WHO: World Health Organization; US-FDA: United States Food and Drug Administration;VTM: Viral transport medium; PANC-1: Pancreatic cancer cell line; DMEM: Dulbecco's modified eagle medium; FBS: Fetal bovine serum; DMSO: Dimethyl sulfoxide.

\section{Supplementary Information}

The online version contains supplementary material available at https://doi. org/10.1186/s12985-021-01642-9.

Additional file 1: All the reference sequences (NCBI GenBank RefSeq) that were available for betacoronaviruses and BLAST results of all LAMP primer binding sites.

Additional file 2: Mapping of identified sequence variants in the primer binding sites.

Additional file 3: Optimization conditions for Lamp reaction.

Additional file 4: Conservation of $L 1$ and $L 2$ primer binding sites in SARSCoV-2 variants

Additional file 5: Validation of RT-LAMP Assay using patient samples (RIL, Mumbai, India).

\section{Acknowledgements}

Authors are thankful to Dr. Inshad Ali Khan (Professor, Department of Microbiology, Central University of Rajasthan) for providing RNA from two COVID-19 positive patients during the beginning of the study. The support provided by Dr Raja Krishnakumar, Dr Kenny Paul, Dr Vikas Patel and Dr Akshay Chawande for the work done at RIL is acknowledged. R\&D of Reliance Industries limited acknowledges the support of Reliance life sciences for providing infrastructural and logistic support.

\section{Authors' contributions}

$V L J$ carried out most of the experimental work related to optimization and validation of RT-LAMP assay, as well as prepared the figures and wrote the manuscript. NK assisted VLJ in development of synthetic templates. RB carried out rt-RT-PCR assays on patient samples. PSJ assisted VL in computational analysis of viral sequences and primers. KS isolated RNA from patient samples. SD was responsible for collection of patient samples and supervised KS. SS was responsible for overall supervision of RNA isolation and rt-RT-PCR of patient samples. MRS, AK and BB independently carried out the validation of optimized RT-LAMP protocol on more than 150 patient samples at their site in Mumbai. MRS helped in study design and supervised AK. RAV and SD provided critical inputs during the study. SGG designed the study; supervised 
VLJ, NK and PSJ, as well as corrected the manuscript. All authors read and approved the final manuscript.

\section{Funding}

Funding support from CSIR-IIIM, CSIR (MLP11001) and RIL is gratefully acknowledged.

\section{Availability of data and materials}

All the datasets used and/or analysis during the current study are available as figures, tables and supplementary files. Any addition information may be obtained from the corresponding author on a reasonable request.

\section{Declarations}

\section{Ethical approval}

This study (C-80/20) was approved by Institutional Ethics Committee (IEC) of Government Medical College (GMC), Jammu (Registration No. ECR/454/Inst/ JK/2013/RR-20).

\section{Consent to publication}

Not applicable.

\section{Competing interests}

Authors declare that they do not have any competing interests.

\section{Author details}

'CSIR-Indian Institute of Integrative Medicine, Canal Road, Jammu 180001, India. ${ }^{2}$ Academy of Scientific and Innovative Research (AcSIR), Ghaziabad 201002, India. ${ }^{3}$ Higher Education Department, Union Territory of Jammu and Kashmir, Jammu, India. ${ }^{4}$ Department of Microbiology, Government Medical College, Jammu 180001, India. ${ }^{5} \mathrm{~A} 2 \mathrm{O}$ - Biology, Reliance Technology Group, Reliance Industries Limited, RCP, Navi Mumbai 400701, India.

Received: 17 March 2021 Accepted: 12 August 2021

Published online: 30 August 2021

\section{References}

1. Cheng VCC, Lau SKP, Woo PCY, Yuen KY. Severe acute respiratory syndrome coronavirus as an agent of emerging and reemerging infection. Clin Microbiol Rev. 2007;20(4):660. https://doi.org/10.1128/CMR.00023-07.

2. Lau SK, Woo PC, Li KS, Huang Y, Tsoi HW, Wong BH, et al. Severe acute respiratory syndrome coronavirus-like virus in Chinese horseshoe bats. Proc Natl Acad Sci U S A. 2005;102(39):14040-5. https://doi.org/10.1073/ pnas.0506735102.

3. Yang X-L, Hu B, Wang B, Wang M-N, Zhang Q, Zhang W, et al. Isolation and characterization of a novel bat coronavirus closely related to the direct progenitor of severe acute respiratory syndrome coronavirus. J Virol. 2015;90(6):3253-6. https://doi.org/10.1128/JVI.02582-15.

4. Azhar El, El-Kafrawy SA, Farraj SA, Hassan AM, Al-Saeed MS, Hashem AM, et al. Evidence for camel-to-human transmission of MERS coronavirus. N Engl J Med. 2014;370(26):2499-505. https://doi.org/10.1056/NEJMoa1401 505.

5. Chu DK, Poon LL, Gomaa MM, Shehata MM, Perera RA, Abu Zeid D, et al. MERS coronaviruses in dromedary camels. Egypt Emerg Infect Dis. 2014:20(6):1049-53. https://doi.org/10.3201/eid2006.140299.

6. Ferretti L, Wymant C, Kendall M, Zhao L, Nurtay A, Abeler-Dörner L, et al. Quantifying SARS-CoV-2 transmission suggests epidemic control with digital contact tracing. Science. 2020;368(6491):eabb6936. https://doi. org/10.1126/science.abb6936.

7. Voysey M, Clemens SAC, Madhi SA, Weckx LY, Folegatti PM, Aley PK, et al. Safety and efficacy of the ChAdOx1 nCoV-19 vaccine (AZD1222) against SARS-CoV-2: an interim analysis of four randomised controlled trials in Brazil, South Africa, and the UK. Lancet. 2021;397(10269):99-111. https:// doi.org/10.1016/s0140-6736(20)32661-1.

8. Li R, Pei S, Chen B, Song Y, Zhang T, Yang W, et al. Substantial undocumented infection facilitates the rapid dissemination of novel coronavirus (SARS-CoV-2). Science. 2020;368(6490):489-93. https://doi.org/10.1126/ science.abb3221.
9. Cherian S, Potdar V, Jadhav S, Yadav P, Gupta N, Das M, et al. Convergent evolution of SARS-CoV-2 spike mutations, L452R, E484Q and P681R, in the second wave of COVID-19 in Maharashtra, India. BioRxivv. 2021. https://doi.org/10.1101/2021.04.22.440932.

10. Lu R, Zhao X, Li J, Niu P, Yang B, Wu H, et al. Genomic characterisation and epidemiology of 2019 novel coronavirus: implications for virus origins and receptor binding. Lancet. 2020;395(10224):565-74. https://doi.org/ 10.1016/s0140-6736(20)30251-8.

11. Naqvi AAT, Fatima K, Mohammad T, Fatima U, Singh IK, Singh A, et al. Insights into SARS-CoV-2 genome, structure, evolution, pathogenesis and therapies: Structural genomics approach. Biochim Biophys Acta Mol Basis Dis. 2020;1866(10):165878. https://doi.org/10.1016/j.bbadis.2020.165878.

12. Davies NG, Abbott S, Barnard RC, Jarvis Cl, Kucharski AJ, Munday J, et al. Estimated transmissibility and severity of novel SARS-CoV-2 variant of concern 202012/01 in England. MedRxiv. 2021;2020-12. https://doi.org/ 10.1101/2020.12.24.20248822

13. To KK-W, Tsang OT-Y, Leung W-S, Tam AR, Wu T-C, Lung DC, et al. Temporal profiles of viral load in posterior oropharyngeal saliva samples and serum antibody responses during infection by SARS-CoV-2: an observational cohort study. Lancet Infect Dis. 2020;20(5):565-74. https://doi.org/10. 1016/S1473-3099(20)30196-1.

14. Zhang W, Du R-H, Li B, Zheng X-S, Yang X-L, Hu B, et al. Molecular and serological investigation of 2019-nCoV infected patients: implication of multiple shedding routes. Emerg Microbes Infect. 2020;9(1):386-9. https://doi.org/10.1080/22221751.2020.1729071.

15. Marlet J, Petillon C, Ragot E, Abou El Fattah Y, Guillon A, Marchand Adam $S$, et al. Clinical performance of four immunoassays for antibodies to SARS-CoV-2, including a prospective analysis for the diagnosis of COVID19 in a real-life routine care setting. J Clin Virol. 2020;132:104633. https:// doi.org/10.1016/j.jcv.2020.104633.

16. Pallett SJC, Rayment M, Patel A, Fitzgerald-Smith SAM, Denny SJ, Charani E, et al. Point-of-care serological assays for delayed SARS-CoV-2 case identification among health-care workers in the UK: a prospective multicentre cohort study. Lancet Respir Med. 2020;8(9):885-94. https://doi.org/10. 1016/S2213-2600(20)30315-5.

17. La Marca A, Capuzzo M, Paglia T, Roli L, Trenti T, Nelson SM. Testing for SARS-CoV-2 (COVID-19): a systematic review and clinical guide to molecular and serological in-vitro diagnostic assays. Reprod Biomed Online. 2020;S1472-6483(1420):30318-27. https://doi.org/10.1016/j.rbmo.2020. 06.001 .

18. Corman VM, Landt O, Kaiser M, Molenkamp R, Meijer A, Chu DK, et al. Detection of 2019 novel coronavirus (2019-nCoV) by real-time RT-PCR. Euro Surveill. 2020. https://doi.org/10.2807/1560-7917.Es.2020.25.3.20000 45.

19. Sheridan C. Coronavirus and the race to distribute reliable diagnostics. Nat Biotechnol. 2020;38(4):382. https://doi.org/10.1038/ d41587-020-00002-2.

20. Esbin MN, Whitney ON, Chong S, Maurer A, Darzacq X, Tjian R. Overcoming the bottleneck to widespread testing: a rapid review of nucleic acid testing approaches for COVID-19 detection. RNA. 2020;26(7):771-83. https://doi.org/10.1261/rna.076232.120.

21. Won J, Lee S, Park M, Kim TY, Park MG, Choi BY, et al. Development of a laboratory-safe and low-cost detection protocol for SARS-CoV-2 of the coronavirus disease 2019 (COVID-19). Exp Neurobiol. 2020;29(2):107-19. https://doi.org/10.5607/en20009.

22. Marinowic DR, Zanirati G, Rodrigues FVF, Grahl MVC, Alcará AM, Machado DC, et al. A new SYBR Green real-time PCR to detect SARS-CoV-2. Sci Rep. 2021;11(1):2224. https://doi.org/10.1038/s41598-021-81245-0.

23. Dorlass EG, Monteiro CO, Viana AO, Soares CP, Machado RRG, Thomazelli LM, et al. Lower cost alternatives for molecular diagnosis of COVID-19: conventional RT-PCR and SYBR Green-based RT-qPCR. Braz J Microbiol. 2020;51(3):1117-23. https://doi.org/10.1007/s42770-020-00347-5.

24. Pereira-Gómez M, Fajardo Á, Echeverría N, López-Tort F, Perbolianachis P, Costábile A, et al. Evaluation of SYBR Green real time PCR for detecting SARS-CoV-2 from clinical samples. J Virol Methods. 2021;289:114035. https://doi.org/10.1016/j.jviromet.2020.114035.

25. Tanner NA, Zhang Y, Evans TC. Visual detection of isothermal nucleic acid amplification using pH-sensitive dyes. Biotechniques. 2015;58(2):59-68. https://doi.org/10.2144/000114253.

26. Quyen TL, Ngo TA, Bang DD, Madsen M, Wolff A. Classification of multiple DNA dyes based on inhibition effects on real-time loop-mediated 
isothermal amplification (LAMP): prospect for point of care setting. Front Microbiol. 2019;10:2234-2234. https://doi.org/10.3389/fmicb.2019.02234.

27. Silva SJRD, Paiva MHS, Guedes DRD, Krokovsky L, Melo FLD, Silva MALD, et al. Development and validation of reverse transcription loop-mediated isothermal amplification (RT-LAMP) for rapid detection of ZIKV in mosquito samples from Brazil. Sci Rep. 2019;9(1):4494. https://doi.org/10. 1038/s41598-019-40960-5.

28. Imai M, Ninomiya A, Minekawa H, Notomi T, Ishizaki T, Tashiro M, et al. Development of H5-RT-LAMP (loop-mediated isothermal amplification) system for rapid diagnosis of $\mathrm{H} 5$ avian influenza virus infection. Vaccine. 2006;24(44):6679-82. https://doi.org/10.1016/j.vaccine.2006.05.046.

29. Parida MM, Santhosh SR, Dash PK, Tripathi NK, Lakshmi V, Mamidi N, et al. Rapid and real-time detection of Chikungunya virus by reverse transcription loop-mediated isothermal amplification assay. J Clin Microbiol. 2007:45(2):351-7. https://doi.org/10.1128/JCM.01734-06.

30. Parida M, Posadas G, Inoue S, Hasebe F, Morita K. Real-time reverse transcription loop-mediated isothermal amplification for rapid detection of West Nile Virus. J Clin Microbiol. 2004;42(1):257. https://doi.org/10.1128/ JCM.42.1.257-263.2004.

31. World Health Organization. Laboratory testing for coronavirus disease (COVID-19) in suspected human cases: interim guidance, 19 March 2020. World Health Organization. https://apps.who.int/iris/handle/10665/ 331501.

32. Mohd Faheem M, Rasool R, Ahmad SM, Jamwal VL, Chakraborty S, Katoch A, et al. Par-4 mediated Smad4 induction in PDAC cells restores canonical TGF- $\beta$ / Smad 4 axis driving the cells towards lethal EMT. Eur J Cell Biol. 2020;99(4):151076. https://doi.org/10.1016/j.ejcb.2020.151076.

33. Awasthi P, Mahajan V, Jamwal VL, Chouhan R, Kapoor N, Bedi YS, et al. Characterization of the gene encoding 4-coumarate:CoA ligase in Coleus forskohlii. J Plant Biochem Biotechnol. 2019;28(2):203-10. https://doi.org/ 10.1007/s13562-018-0468-4.

34. Venkatesan P. Estimate of COVID-19 case prevalence in India based on surveillance data of patients with severe acute respiratory illness. medRxiv. 2020.04.14.20065342. https://doi.org/10.1101/2020.04.14.20065 342

35. Younes N, Al-Sadeq DW, Al-Jighefee H, Younes S, Al-Jamal O, Daas HI, et al. Challenges in laboratory diagnosis of the novel coronavirus SARS-CoV-2. Viruses. 2020;12(6):582. https://doi.org/10.3390/v12060582.

36. Adebisi YA, Oke GI, Ademola PS, Chinemelum IG, Ogunkola IO, LuceroPrisno lii DE. SARS-CoV-2 diagnostic testing in Africa: needs and challenges. Pan Afr Med J. 2020;35(Suppl 2):4-4. https://doi.org/10.11604/ pamj.2020.35.4.22703.

37. Jin H, Wang H, Li X, Zheng W, Ye S, Zhang S et al. Estimating the Cost-ofIllness Associated with the COVID-19 Outbreak in China from January to March 2020 (5/7/2020). Available at SSRN: https://ssrn.com/abstract= 3605091 or https://doi.org/10.2139/ssrn.3605091. medRxiv. 2020.

38. Nicola M, Alsafi Z, Sohrabi C, Kerwan A, Al-Jabir A, losifidis C, et al. The socio-economic implications of the coronavirus pandemic (COVID-19): a review. Int J Surg. 2020;78:185-93. https://doi.org/10.1016/j.jsu.2020.04. 018.

39. Park G-S, Ku K, Baek S-H, Kim S-J, Kim Sl, Kim B-T, et al. Development of reverse transcription loop-mediated isothermal amplification assays targeting severe acute respiratory syndrome coronavirus 2 (SARS-CoV-2). J Mol Diagn. 2020;22(6):729-35. https://doi.org/10.1016/j.jmoldx.2020.03. 006.
40. Huang WE, Lim B, Hsu C-C, Xiong D, Wu W, Yu Y, et al. RT-LAMP for rapid diagnosis of coronavirus SARS-CoV-2. Microb Biotechnol. 2020;13(4):95061. https://doi.org/10.1111/1751-7915.13586.

41. Yan C, Cui J, Huang L, Du B, Chen L, Xue G, et al. Rapid and visual detection of 2019 novel coronavirus (SARS-CoV-2) by a reverse transcription loop-mediated isothermal amplification assay. Clin Microbiol Infect. 2020;26(6):773-9. https://doi.org/10.1016/j.cmi.2020.04.001.

42. Dao Thi VL, Herbst K, Boerner K, Meurer M, Kremer LPM, Kirrmaier D, et al. A colorimetric RT-LAMP assay and LAMP-sequencing for detecting SARSCoV-2 RNA in clinical samples. Sci Transl Med. 2020;12(556):eabc7075. https://doi.org/10.1126/scitranslmed.abc7075.

43. Yang P, Wang X. COVID-19: a new challenge for human beings. Cell Mol Immunol. 2020;17(5):555-7. https://doi.org/10.1038/s41423-020-0407-X.

44. Zhou P, Yang X-L, Wang X-G, Hu B, Zhang L, Zhang W, et al. A pneumonia outbreak associated with a new coronavirus of probable bat origin. Nature. 2020;579(7798):270-3. https://doi.org/10.1038/ s41586-020-2012-7.

45. Altamimi A, Ahmed AE. Climate factors and incidence of Middle East respiratory syndrome coronavirus. J Infect Public Health. 2020;13(5):704-8. https://doi.org/10.1016/j.jiph.2019.11.011.

46. Elkholy AA, Grant R, Assiri A, Elhakim M, Malik MR, Van Kerkhove MD. MERS-CoV infection among healthcare workers and risk factors for death: retrospective analysis of all laboratory-confirmed cases reported to WHO from 2012 to 2 June 2018. J Infect Public Health. 2020;13(3):418-22. https://doi.org/10.1016/j.jiph.2019.04.011.

47. Chan W-M, Ip JD, Chu AW-H, Yip CC-Y, Lo L-S, Chan K-H et al. Identification of nsp1 gene as the target of SARS-CoV-2 real-time RT-PCR using nanopore whole-genome sequencing. J Med Virol. 2020;92(11):2725-34. https://doi.org/10.1002/jmv.26140.

48. Dhama K, Karthik K, Chakraborty S, Tiwari R, Kapoor S, Kumar A, et al. Loop-mediated isothermal amplification of DNA (LAMP): a new diagnostic tool lights the world of diagnosis of animal and human pathogens: a review. Pak J Biol Sci. 2014;17(2):151-66. https://doi.org/10.3923/pjbs. 2014.151.166

49. Garafutdinov RR, Gilvanov AR, Sakhabutdinova AR. The influence of reaction conditions on DNA multimerization during isothermal amplification with Bst exo-DNA Polymerase. Appl Biochem Biotechnol. 2020;190(2):758-71. https://doi.org/10.1007/s12010-019-03127-6.

50. Wang G, Ding X, Hu J, Wu W, Sun J, Mu Y. Unusual isothermal multimerization and amplification by the strand-displacing DNA polymerases with reverse transcription activities. Sci Rep. 2017;7(1):13928-13928. https:// doi.org/10.1038/s41598-017-13324-0.

51. Wong YP, Othman S, Lau YL, Radu S, Chee HY. Loop-mediated isothermal amplification (LAMP): a versatile technique for detection of micro-organisms. J Appl Microbiol. 2018;124(3):626-43. https://doi.org/10.1111/jam. 13647.

52. Kucirka LM, Lauer SA, Laeyendecker O, Boon D, Lessler J. Variation in false-negative rate of reverse transcriptase polymerase chain reactionbased SARS-CoV-2 tests by time since exposure. Ann Intern Med. 2020;173(4):262-7. https://doi.org/10.7326/M20-1495

\section{Publisher's Note}

Springer Nature remains neutral with regard to jurisdictional claims in published maps and institutional affiliations. 